\title{
HYPERSPECTRAL IMAGING IN INFRARED REGION USING COMPRESSED SENSING METHODS
}

\author{
Jiří Hlubuček ${ }^{1}$; Karel Žídek ${ }^{2}$ \\ Institute of Plasma Physics, Academy of Sciences of the Czech Republic, \\ Regional Centre for Special Optics and Optoelectronic Systems (TOPTEC), \\ Za Slovankou 1782/3, 18200 Prague 8, Czech Republic \\ e-mail: ${ }^{1}$ hlubucek@ipp.cas.cz; ${ }^{2}$ zidek@ipp.cas.cz
}

\begin{abstract}
We provide a review of hyperspectral imaging in infrared region as well as simulation of measurements and reconstructions of test datacubes using the compressed sensing method CASSI (Coded Aperture Snapshot Spectral Imaging). We simulate the presence of the chemical compounds on parts of the image and then we reconstruct its absorption spectrum and localization back from a single snapshot. In other words, we prove that in principle it is possible to reconstruct a sparse $3 \mathrm{D}$ datactube from a single 2D dataset. Furthermore, we discuss the quality of the reconstructed data and limitations of the chosen simulation method.
\end{abstract}

\section{Keywords}

Hyperspectral imaging; Infrared spectrum; Spectroscopy; Compressed sensing.

\section{Introduction}

Hyperspectral imaging (HSI) refers to all methods where, besides image information, we obtain also the spectrum of light at each point of the image. Hyperspectral imaging in infrared (IR) region is important because it could give us an enormous amount of information of the scene of our interest which we are not able to acquire in any other mean, e.g. remote sensing of the chemical composition. For this reason, the field of HSI has been very lively in the past decades.

A specific task of HSI is to carry out imaging in the IR region. It is worth noting that this article focuses on the IR region which is beyond the scope of conventional optics and detectors, i.e. we consider the so-called middle and far infrared $(\lambda>2.5 \mu \mathrm{m})$. HSI in the IR is not widespread due to the need of using unusual optical materials and detectors.

A possible solution to this problem is using compressed sensing methods. Compressed sensing denotes a signal processing technique which exploits the essence of natural signals that is not obvious at the first sight. The natural signals are sparse which means you can recover them from far fewer measurements than it is required by the Shannon-Nyquist theorem. Basically, you acquire and reconstruct the signals by finding solutions to underdetermined linear systems. More details can be found in [1].

\section{Research Objective}

This article comprehensively deals with the possibility of using compressed sensing in HSI in the IR region, which would allow a simpler construction of HSI devices. An overview of the published results on this topic is supplemented by samples of reconstructions of artificial data (hyperspectral scenes) where we simulate the presence of the chemical compounds on parts of the image and then we reconstruct its absorption spectrum back. We simulate spectrally 
constant irradiation of the studied scene, as well as the radiation of the black body. The main goal of this article is to evaluate feasibility of using the CASSI method in the IR HSI.

\section{Experimental Methods}

Data simulations and reconstructions were performed using Matlab. Two types of scenes were selected for the reconstruction - a simple and a more complex scene. The simple one was a scene with constant intensity in every pixel, while the one more complex was an image of a real scene captured by an infrared camera. For every type of scene a few different variants were evaluated. The variables were size of the scene $(32 \times 32,64 \times 64,128 \times 128, \ldots)$, the number of wavelengths $(117,235,470, \ldots)$ and concentration of the chemical substance.

As a chemical substance we used isopropyl alcohol. The results shown in this article are for path concentration of $500 \mathrm{ppm} \mathrm{m}$. The IR spectrum for isopropyl alcohol was obtained from The National Institute of Standards and Technology (NIST), the data were compiled by: P.M. Chu, F.R. Guenther, G.C. Rhoderick, and W.J. Lafferty with parameters IFS66V (Bruker); 3Term B-H Apodization and resolution of $0.4820 \mathrm{~cm}-1$.

For simulation of compressed sensing we focused on the so-called method CASSI (Coded Aperture Snapshot Spectral Imaging), which is described in more detail below or in literature [1]. This method is one of the standard methods of compressed scanning.

We used the TwIST (Two-Step Iterative Shrinkage/Thresholding) algorithm for image restoration during the reconstruction to minimize expression (1)

$$
f(x)=\frac{1}{2}\|y-K x\|^{2}+\lambda \Phi(x)
$$

where $K$ is the linear direct operator, $\Phi$ is a regularizer, and $\lambda$ is a regularization parameter [2].

\subsection{Hyperspectral Imaging in IR}

Infrared (IR) electromagnetic spectrum can be divided into three regions:

- Near IR - 13,500 - $4000 \mathrm{~cm}-1$

- Mid IR - 4000-400 cm-1

- Far IR - 400-10 cm-1

Definition of these regions can slightly differ through scientific literature.

Each chemical compound has a characteristic absorption spectrum in the IR region. This is due to the changes in vibrational and rotational energy of the chemical bonds of the molecules while they interact with the IR radiation and also because quantum mechanics allows only a few energy levels $[3,4]$.

Hyperspectral imaging (HSI), also known as chemical or spectroscopic imaging, is a technique that combines conventional imaging with spectroscopic systems in order to obtain both spatial and spectral information. IR spectroscopy, which is the core of the IR-HSI, is based on the interaction of IR light with molecules of the sample examined. The result of this interaction can be characterized by absorption, reflection and emission. Absorption in the near-IR region is relatively shallow [4], therefore in this article we focus on the mid- and farIR region. Fundamentals and development of IR spectroscopy can be found in publications [5, $6,7]$.

In classical spectroscopy, a spectrum is integral spectral information about the sample surface, which is dependent on the size of the irradiated spot, i.e. we obtain only a single spectrum. In hyperspectral imaging, the measurement results in a three-dimensional data array called 
"datacube" - each pixel is assigned to one spectrum. We can also imagine the datacube as a stack of papers where each sheet of paper denotes the sample at different wavelength.

For a better idea of how this datacube is obtained, here are examples of the basic types of configurations of devices for obtaining hyperspectral information.

1. Point mapping - The sample is scanned point by point, and for each such point one spectrum is acquired.

2. Line Scan - The detector records the spectral information for the entire line of pixels of the image simultaneously; the light passes through the slit on the detector, so it is possible to record the spectral information along the entire line depending on the location from which the light comes; in this way a two-dimensional array is obtained which has one spectral dimension and one spatial dimension; for the second spatial dimension of the datacube, we need to scan the sample in a direction perpendicular to the imaging line.

3. Plane scan - This type of configuration does not require any movement of the sample (or spatial scanning), so it is also referred to as "staring configuration"; the incoming light is recorded on the detector as a two-dimensional spatial array for each wavelength separately; this is achieved by means of filters (band-pass filters [8] or adjustable acoustooptic filters [9]) which can be placed on a revolving disc or change the passing wavelength respectively [1].

Two basic configurations listed above that use the translational motion of the sample are whisker-broom and push-broom scans. These methods have excellent spatial and spectral resolution; however, from the principle it implies that the acquisition time is very long, in the order of tens of minutes to hours, depending on the size of the scanned area, the wavelength range and the number of scans per pixel [3]. On the contrary, when using a plane scan we are able to record a complete datacube in a matter of seconds or minutes, depending on the number of scanned wavelengths. This can be especially used to explore processes that are unstable in time.

Hyperspectral camera contains: the light source (or uses a scattered ambient light), beam splitters (tunable filters, diffraction gratings, Fourier transformation spectrometers [10]), imaging lenses, detector, motion control / motion sensing devices to obtain very accurate spatial information.

HSI is used in many different fields, e.g. medical applications [11], quality control and food analysis [12,13], forensic sciences [14, 15], art conservation [16], etc.

\subsection{Compressed Sensing}

Recording, "storing", and processing a datacube are very demanding with respect to time, computing power, data storage and what is more, in conventional signal processing, we are limited by the so-called Shannon-Nyquist theorem, which tells us that for the correct reconstruction of the signal the sampling frequency must be at least twice as high as the highest frequency present in the signal. However, this is very inconvenient in accordance to capture very fast processes (e.g. quantum dots) or in the IR region, where we are very limited by the structural elements of IR cameras and their high purchase price.

Shannon-Nyquist theorem and processing very large datasets can be bypassed by the method called compressed sensing (CS), which uses two assumptions - sparsity of a signal and incoherence. 


\subsubsection{Sparsity of a Signal}

If a signal contains only a small percentage of important information, the signal is denoted to be sparse - it can be written very concisely in the correctly chosen base $\psi$. For example, a conventional camera captures the scene, pixel by pixel, and consequently from the knowledge of "important points", it compresses the scene into a JPEG format that is many times smaller than the RAW data, all without apparent loss of image quality.

\subsubsection{Incoherence}

A signal having a sparse representation in $\psi$ must be spread out in the domain in which it was recorded. For example, the peak in the time domain is spread out in the frequency domain [1].

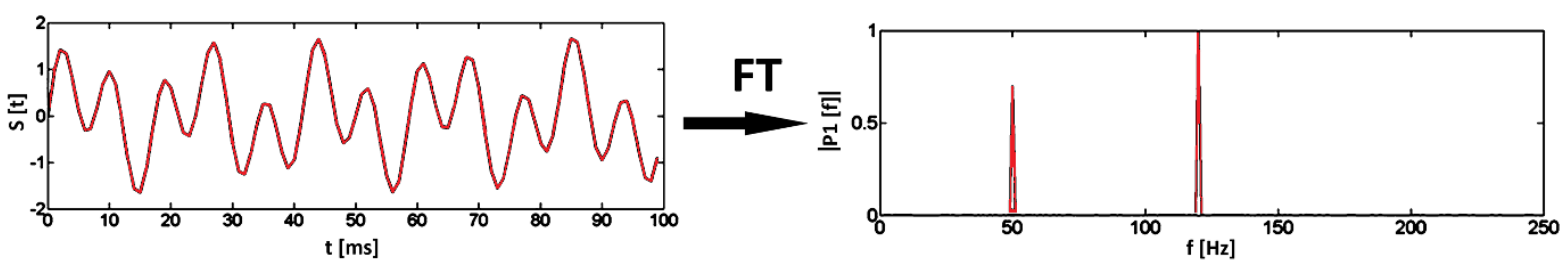

Source: Own

Fig. 1: Fourier transform of the signal from time domain to frequency domain

In Fig. 1 we see that the relatively complex signal displayed in the time domain has a very sparse representation in the frequency domain, which similarly works for the video signal. Speaking about the JPEG compression example above, typically, a 1Mpx image can be compressed to $2.5 \%$ of the original size without apparent loss of the image quality by using 25000 strongest Fourier transform coefficients. The problem is that we are not able to compress the scene until we capture it because we generally do not know which pixels will carry the important information about the image.

If we capture the scene pixel by pixel, we are very limited by the acquisition time for recording very fast processes. Conversely, compressed sensing is able to encode the whole scene in a single instant using a random mask, and then to reconstruct the image exploiting its knowledge. This makes it possible to capture events taking place in the order of dozens of ps [17].

The so-called CASSI (Coded Aperture Snapshot Spectral Imaging) method exploits a coded aperture and dispersive element(s) to modulate the optical field from the scene, which is captured in one instance on the detector into the two-dimensional snapshot. As a coded aperture a random mask (i.e. random binary pattern) can be used. An example of the random mask can be seen in Fig. 2 (middle). The random mask blocks or passes the light coming inside the aperture depending on the binary value of the pixel. The random mask blocks approximately $1 / 2$ of the incoming light and the pixel columns in the mask should be independent.

It is worth nothing that by CASSI we capture 3D information onto $2 \mathrm{D}$ detector. However, we can retrieve the $3 \mathrm{D}$ information back because we know the structure of the pattern (random mask) we used to encode the scene and we presume that the signal is sparse. Hence, we are able to reconstruct the scene by an algorithm calculating equation (1) [1].

\subsection{Using Compressed Sensing in IR Hyperspectral Imaging}

Absorption in the mid-IR corresponds to the fundamental vibrational states of the chemical bonds. When the molecule interacts with IR light, chemical bonds begin to vibrate more 
energetically, and thus affect absorption at certain wavelengths in the spectrum that is characteristic for each chemical bond.

On contrary, the ability to absorb near-IR is relatively small and depends on the harmonic and anharmonic movement of molecules, which is due to electronic transitions. Therefore, this technique is also called electronic or vibrational spectroscopy [4].

There are only few articles dealing with application of CS in mid- and far-IR HSI, e.g. [18, 19, 20]. The lack of publications could be attributed to the difficulties connected to the need of special optic elements and detectors in IR region.

\section{Simulation of Hyperspectral Datacubes and their Reconstruction}

We used a plain scene as well as a more complicated one, see Fig. 2 (left). In the terms of the plain scene, we used the same intensity in each pixel, i.e. in real situation (capturing the IR image) it would mean that we detected constant temperature through the whole scene.

\subsection{Synthetic Data Preparation}

For simulation of capturing the scene through CASSI method, we placed a chemical substance on part of the scene, which caused distinguishable difference in image intensity at specific slices of a datacube in accordance with the absorption spectrum of the chemical substance. In terms of computation, we have to multiply our scene (2D) with the transmission spectrum (1D) of the chemical compound. That is how we obtain the 3D datacube. Then (optionally) we add nonlinear Planck's law, i.e. black body radiation which is wavelength dependent. After that we apply a random mask to every slice of the datacube, see Fig. 2 (right).
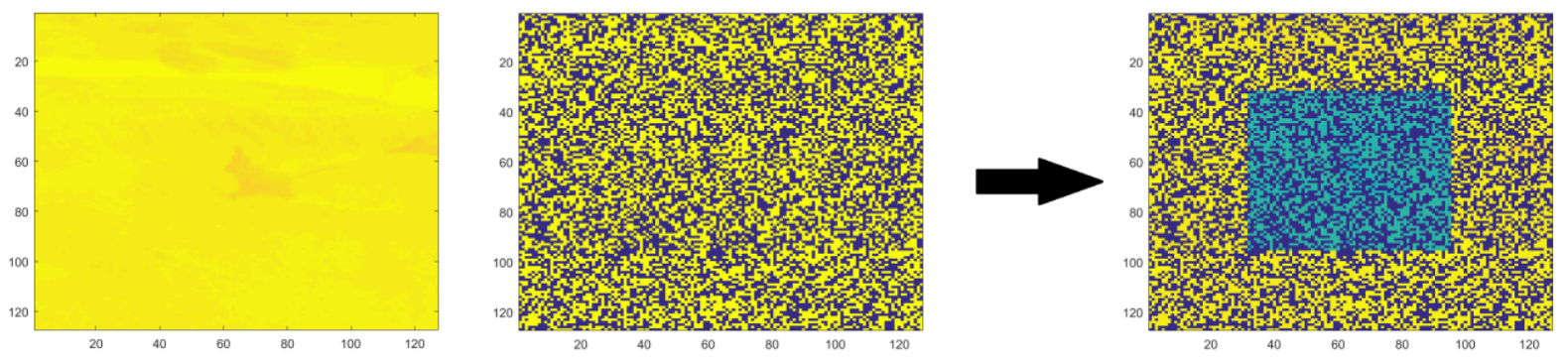

Source: Own

Fig. 2: Example of the scene $128 \times 128$ (left), random mask (middle), slice of the datacube with applied chemical substance on the scene (right)

\subsection{Detector Signal}

Detecting the 3D information on 2D detector could seem illogical, however, as mentioned above, we can retrieve the 3D information back from the knowledge of the random mask pattern and knowing the captured signal is sparse.

During detection of the signal, the IR spectrum coming to the IR optics of a hyperspectral camera would be refracted to different positions on the detector depending on the wavelength. In our simulation, when we work with an image size of 64x64 pixels and using 200 wavelengths, every wavelength (i.e. every slice) would be shifted by one pixel to the right on the detector, i.e. the image is spectrally sheared. The first slice would be in position 1-64, the second slice 2-65 and so on; hence the detector has to be $64 \times 263$ pixels to capture the whole datacube. The intensities of the slices are summed up in according positions creating the shear pattern on the detector, see Fig. 3 (middle). 

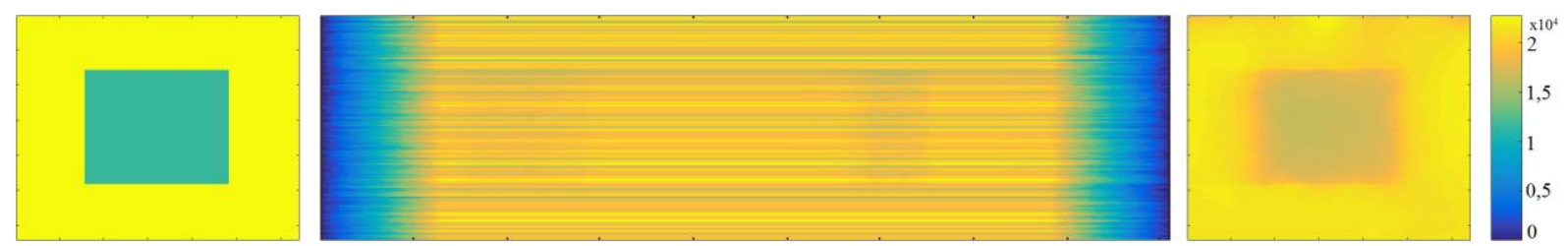

Source: Own

Fig. 3: Reconstruction of the plain scene. Original scene (left), detected image at the detector (middle), reconstructed scene (right).

In Fig. 3 (left) we can see the example of one slice of the datacube. For the sake of demonstration, we selected the wavelength in which the absorption was most significant. We show only one wavelength for the original and reconstructed scene, but in fact there are many different wavelengths which are altogether composing the datacube (every wavelength denotes one slice in the datacube).

\subsection{Reconstructing Data}

For reconstruction of the data we used TwIST (Two-Step Iterative Shrinkage/Thresholding) algorithm, which is an improved version of standard IST algorithm [20]. For each slice of the original datacube, we obtain one slice of the reconstructed datacube. From the reconstructed slices we take the sum of the area of where was the chemical compound applied in the original image and put it into a graph depending on wavelength to obtain the reconstructed intensity spectrum as can be seen in Fig. 4 (right).
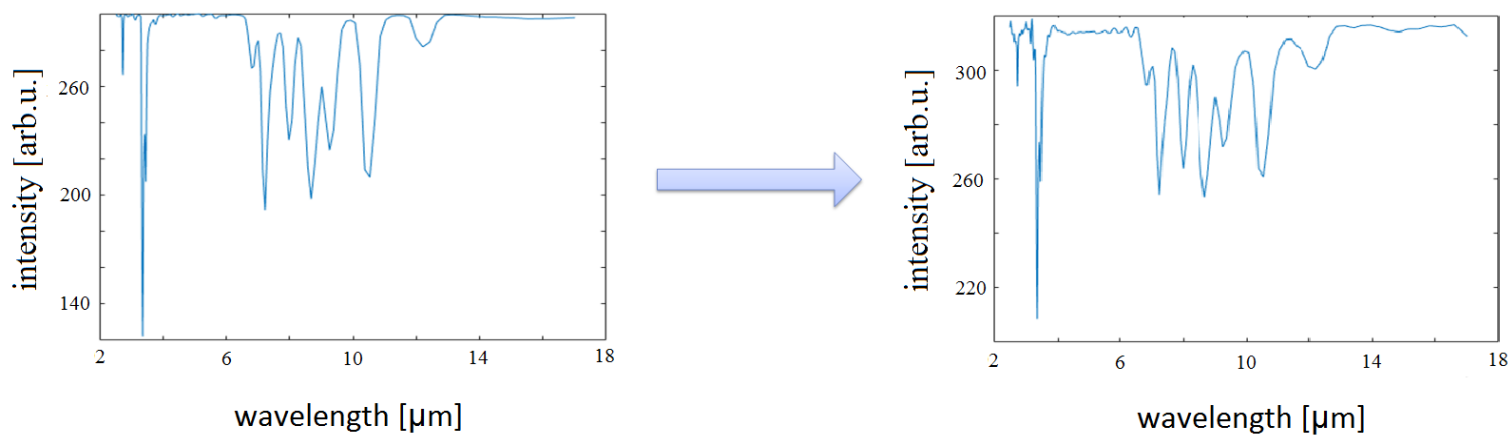

Source: Own

Fig. 4: Original spectrum (left) vs. reconstructed spectrum (right) of plain scene

In Fig. 4, we can see that the total intensities of the reconstructed spectrum are not the same as in the original one, but the position of the peaks/dips and their relative intensity to each other are particularly important in order to successfully distinguish the type and volume of the chemical compound measured.

The reconstructed spectrum can be used for recognition of the chemical compound. Simulations with the plain scene granted better results over the usage of the more complex one. The reconstructed complex scene lacks details, therefore the results (from visual point of view) look very similar to the plain scene. As can be seen in Fig. 3 (right), the area where the chemical compound was, is authentically depicted. However, when we include the Planck's law (black body radiation) into the simulation, the quality of the reconstructed spectrum and the resolution of the slices of the datacube reduce greatly (results not shown).

\section{Conclusion}

In this article, we have provided an overview of IR hyperspectral imaging, with particular attention to using compressed sensing. We also created testing hyperspectral datacubes, in 
which we simulated their measurements by the CASSI method. The simulated measurements were subsequently reconstructed by the TwIST algorithm.

We have found that we are able to obtain good results only with simulations of a plain scene. When we simulate a measurement of a more complex scene, we do not achieve a sufficient reconstruction quality and in the case of using black body radiation the CASSI method cannot be directly applied in this particular layout. One of the possible issues could be the reconstruction algorithm and the aim of the further research will be the use of, for example, several measurements of different random masks or rotation of spectral sweeping.

\section{Acknowledgements}

We gratefully acknowledge the financial support of the Ministry of Education, Youth and Sports of the Czech Republic (Project NPU LO1206).

\section{Literature}

[1] ARCE, G. R.; BRADY, D. J.; CARIN, L.; ARGUEllO, H.; KITTLE, D. S.: Compressive Coded Aperture Spectral Imaging: An Introduction. IEEE Signal Processing Magazine. 2014, 31(1), pp. 105-115. Available from WWW: https://ieeexplore.ieee.org/document/6678264/. DOI: 10.1109/MSP.2013.2278763

[2] BIOUCAS-DIAS, J. M.; FIGUEIREDO, M. A. T.: A New TwIST: Two-Step Iterative Shrinkage/Thresholding Algorithms for Image Restoration. IEEE Transactions on Image Processing. 2007, 16(12), pp. 2992-3004. Available from WWW: https://ieeexplore.ieee.org/document/4358846/. DOI: 10.1109/TIP.2007.909319

[3] GENDRIN, C.; ROGGO, Y.; COLLET, C.: Pharmaceutical applications of vibrational chemical imaging and chemometrics: A review. Journal of Pharmaceutical and Biomedical Analysis. 2008, 48(3), pp. 533-553. DOI: 10.1016/j.jpba.2008.08.014

[4] STUART, B. H.: Infrared Spectroscopy: Fundamentals and Applications. Wiley Press: London, UK, 2004, pp. 29-36. ISBN 978-0-470-85428-0.

[5] MANLEY, M.: Near-infrared spectroscopy and hyperspectral imaging: Non-destructive analysis of biological materials. Chemical Society Reviews. 2014, 43(24), pp. 82008214. DOI: $10.1039 / \mathrm{C} 4 \mathrm{CS} 00062 \mathrm{E}$

[6] HUCK, Ch. W.; OZAKI, Y.; VERENA, A.; HUCK-PEZZEI, V. A.: Critical Review Upon the Role and Potential of Fluorescence and Near-Infrared Imaging and Absorption Spectroscopy in Cancer Related Cells, Serum, Saliva, Urine and Tissue Analysis. Current Medicinal Chemistry. 2016, 23(27), pp. 3052-3077. DOI: $\underline{10.2174 / 0929867323666160607110507}$

[7] TÜRKER-KAYA, S.; HUCK, Ch. W.: A Review of Mid-Infrared and Near-Infrared Imaging: Principles, Concepts and Applications in Plant Tissue Analysis. Molecules. 2017, 22(1), p. 168. DOI: $10.3390 /$ molecules22010168

[8] JUNKERMANN, W.; BURGER, J. M.: A New Portable Instrument for Continuous Measurement of Formaldehyde in Ambient Air. Journal of Atmospheric and Oceanic Technology. 2006, 23(1), pp. 38-45. DOI: 10.1175/JTECH1831.1

[9] KATRAŠNIK, J.; BÜRMEN, M.; PERNUŠ, F.; LIKAR, B.: Spectral characterization and calibration of AOTF spectrometers and hyper-spectral imaging systems. Chemometrics and Intelligent Laboratory Systems. 2010, 101(1), pp. 23-29. DOI: $\underline{10.1016 / j . c h e m o l a b .2009 .11 .012}$ 
[10] HAMMOND, S. V.; CLARKE, F. C.: The handbook of vibrational spectroscopy, sampling techniques, microscopy. In: Chalmers J. M.; Griffiths P. R. (eds), Wiley, Hoboken, 2002, pp. 1405-1431.

[11] CARRASCO, O.; GOMEZ, R. B.; CHAINANI, A.; ROPER, W. E.: Hyperspectral imaging applied to medical diagnoses and food safety. In: Proc. SPIE 5097, GeoSpatial and Temporal Image and Data Exploitation III. (14 August 2003). DOI: $\underline{10.1117 / 12.502589}$

[12] MAHESH, S.; JAYAS, D. S.; PALIWAL, J.; WHITE, N. D. G.: Hyperspectral imaging to classify and monitor quality of agricultural materials. Journal of Stored Products Research. 2015, Vol. 61, pp. 17-26. DOI: 10.1016/j.jspr.2015.01.006

[13] FENG, Y.-Z; SUN, D.-W.: Application of hyperspectral imaging in food safety inspection and control: a review. Critical Reviews in Food Science and Nutrition. 2012, 52(11), pp. 1039-1058. DOI: 10.1080/10408398.2011.651542

[14] SCHULER, R. L.; KISH, P. E.; PLESE, C. A.: Preliminary observations on the ability of hyperspectral imaging to provide detection and visualization of bloodstain patterns on black fabrics. Journal of Forensic Sciences. 2012, 57(6), 1562-1569. DOI: $10.1111 / \mathrm{j} .1556-4029.2012 .02171 . \mathrm{X}$

[15] EDELMAN, G. J.; GASTON, E.; van LEEUWEN, T. G.; CULLEN, P. J.; AALDERS, M. C. G.: Hyperspectral imaging for non-contact analysis of forensic traces. Forensic Science International. 2012, 223(1-3), pp. 28-39. DOI: 10.1016/j.forsciint.2012.09.012

[16] BALAS, C.; EPITROPOU, G.; TSAPRAS, A.; HADJINICOLAOU, N.: Hyperspectral imaging and spectral classification for pigment identification and mapping in paintings by El Greco and his workshop. Multimedia Tools and Applications. 2018, 77(8), pp. 9737-9751. DOI: $10.1007 / \mathrm{s} 11042-017-5564-2$

[17] GAO, L.; LIANG, J.; LI, Ch.; WANG, L. V.: Single-shot compressed ultrafast photography at one hundred billion frames per second. Nature. 2014, Vol. 516, pp. 7477. DOI: $10.1038 /$ nature 14005

[18] FERNANDEZ, Ch. A.; GUENTHER, B. D.; GEHM, M. E.; BRADY, D. J.; SULLIVAN, M. E.: Longwave infrared (LWIR) coded aperture dispersive spectrometer. Frontiers in Optics. 2006, OSA Technical Digest (CD) (Optical Society of America, 2006), paper JSuA10. DOI: 10.1364/FIO.2006.JSuA10

[19] RUSSELL, T. A.; McMACKIN, L.; BRIDGE, B.; BARANIUK, R.: Compressive hyperspectral sensor for LWIR gas detection. Proc. SPIE 8365, Compressive Sensing. 2012, 83650C. DOI: $10.1117 / 12.919522$

[20] DUPUIS, J. R.; KIRBY, M.; COSOFRET, B. R.: Longwave infrared compressive hyperspectral imager. Proc. SPIE 9482, Next-Generation Spectroscopic Technologies VIII. 2015, 94820Z. DOI: $\underline{10.1117 / 12.2177893}$

Ing. Jiř́i Hlubuček; RNDr. Karel Žídek, Ph.D. 


\section{HYPERSPEKTRÁLNÍ ZOBRAZOVÁNÍ V INFRAČERVENÉ OBLASTI VYUŽÍVAJIICÍ KOMPRIMOVANÉ SNÍMÁNÍ}

Tento článek se zabývá hyperspektrálním zobrazováním v infračervené oblasti, simulacemi měření a rekonstrukcemi testovacích datakrychlí za použití metody komprimovaného snímání CASSI (Coded Aperture Snapshot Spectral Imaging). Provedli jsme simulace prítomnosti chemické látky na části obrazu a poté jsme zrekonstruovali její absorpční spektrum a lokalizovali ji z jediného snímku detektoru. Jinými slovy, ukázali jsme, že v podstatě je možné rekonstruovat ř́́dkou 3D datakrychli z jediného 2D obrazu. Dále diskutujeme kvalitu rekonstruovaných dat a limity zvolených metod simulace.

\section{HYPERSPEKTRALES ABBILDEN IM INFRAROTEN BEREICH ZUR ANWENDUNG KOMPRIMIERTEN SCANNENS}

Dieser Artikel befasst sich mit dem hyperspektralen Abbilden im infraroten Bereich, mit Simulationen des Messens und mit Rekonstruktionen von Testdatenwürfeln unter Verwendung der Methode des komprimierten Scannens, genannt CASSI (Coded Aperture Snapshot Spectral Imaging). Wir haben Simulationen der Gegenwart eines chemischen Stoffes auf einem Teil des Bildes durchgeführt. Danach haben wir dessen Absorptionsspektrum rekonstruiert und es auf einer einzigen Aufnahme des Detektors lokalisiert. Mit anderen Worten haben wir gezeigt, dass es im Grunde möglich ist, den seltenen 3D-Datenwürfel auf einem einzigen 2D-Bild zu rekonstruieren. Weiter diskutieren wir die Qualität der rekonstruierten Daten und die Grenzen der gewählten Methoden der Simulation.

\section{OBRAZOWANIE WIELOSPEKTRALNE W ZAKRESIE PODCZERWIENI PRZY WYKORZYSTANIU TECHNIKI COMPRESSED SENSING}

Niniejszy artykuł poświęcony jest obrazowaniu wielospektralnemu w zakresie podczerwieni, symulacjom pomiaru i odtwarzaniu testowych kostek danych przy wykorzystaniu metody compressed sensing CASSI (Coded Aperture Snapshot Spectral Imaging). Przeprowadziliśmy symulację obecności substancji chemicznej na części obrazu, po czym odtworzyliśmy jej widmo absorpcyjne i zlokalizowaliśmy ją z jednego obrazu zarejestrowanego przez czujnik. Innymi słowy, pokazaliśmy, że w zasadzie można odtworzyć niezbyt gęstą kostkę danych 3D $\mathrm{z}$ jednego tylko obrazu 2D. Ponadto omawiamy jakość odtworzonych danych oraz ograniczenia wybranych metod symulacyjnych. 